\title{
Laboratory for Characterization of Irradiated Graphite
}

\author{
William Windes
}

March 2010

The INL is a

U.S. Department of Energy

National Laboratory

operated by

Battelle Energy Alliance

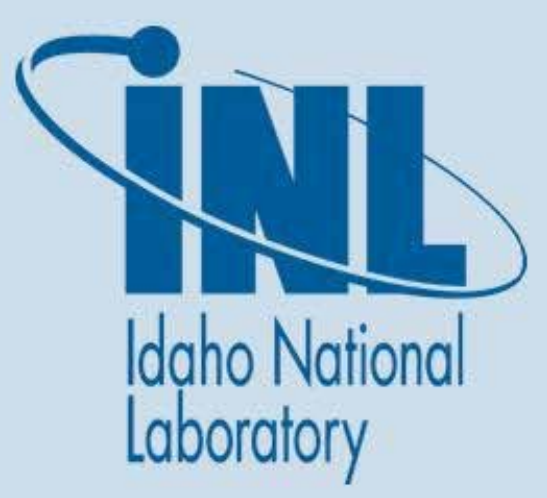

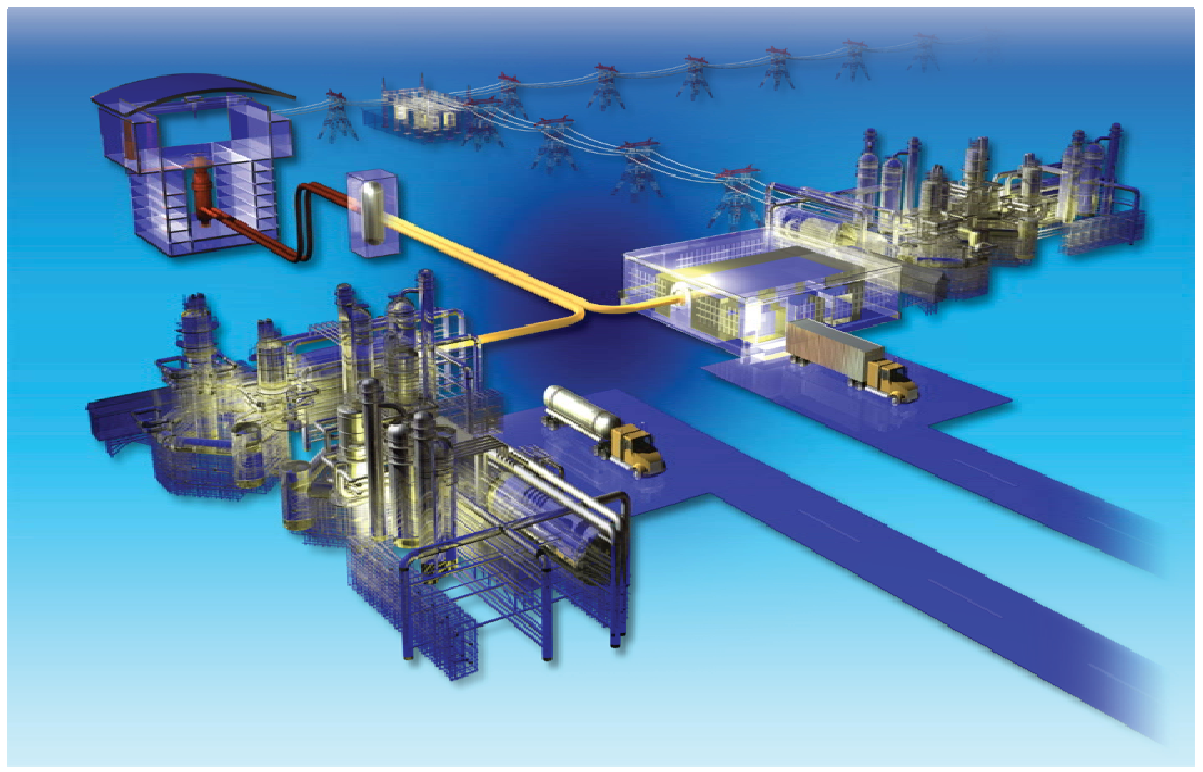

The INL is a U.S. Department of Energy National Laboratory operated by Battelle Energy Alliance. 


\section{DISCLAIMER}

This information was prepared as an account of work sponsored by an agency of the U.S. Government. Neither the U.S. Government nor any agency thereof, nor any of their employees, makes any warranty, expressed or implied, or assumes any legal liability or responsibility for the accuracy, completeness, or usefulness, of any information, apparatus, product, or process disclosed, or represents that its use would not infringe privately owned rights. References herein to any specific commercial product, process, or service by trade name, trade mark, manufacturer, or otherwise, does not necessarily constitute or imply its endorsement, recommendation, or favoring by the U.S. Government or any agency thereof. The views and opinions of authors expressed herein do not necessarily state or reflect those of the U.S. Government or any agency thereof. 
INL/EXT-10-18039

\title{
Laboratory for Characterization of Irradiated Graphite
}

\author{
William Windes
}

March 2010

\begin{abstract}
Idaho National Laboratory Next Generation Nuclear Plant Project Idaho Falls, Idaho 83415
\end{abstract}

Prepared for the

U.S. Department of Energy

Office of Nuclear Energy

Under DOE Idaho Operations Office

Contract DE-AC07-05ID14517 



\section{Next Generation Nuclear Plant Project}

\section{Laboratory for Characterization of Irradiated Graphite}

INL/EXT-10-18039

March 2010

Approved by:

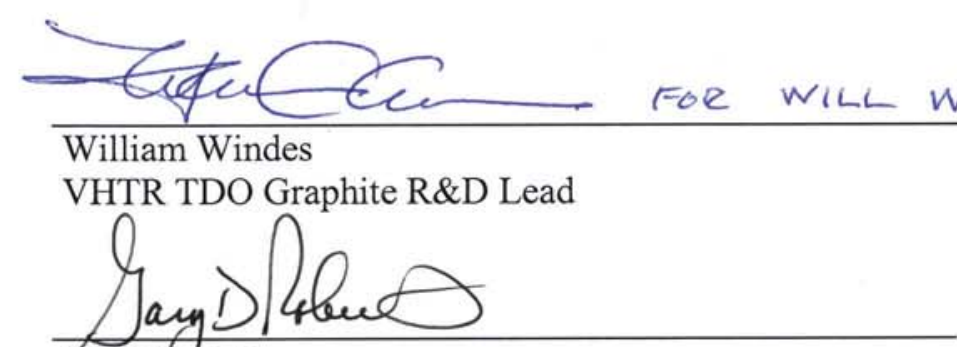

tary Roberts

VHTR TDO Graphite R\&D QA

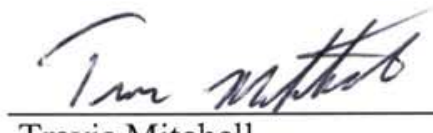

Travis Mitchell

VHTR TDO Graphite R\&D Project Management
Date
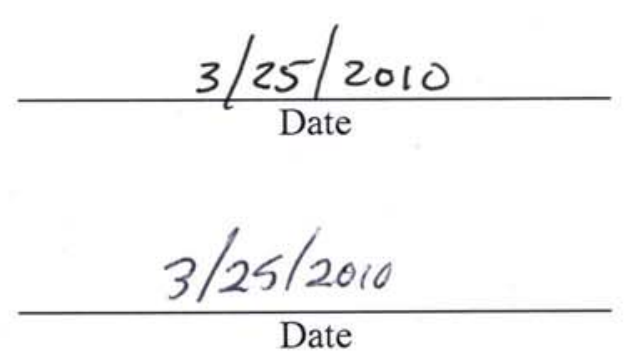


\begin{abstract}
The newly completed Carbon Characterization Laboratory (CCL) is located in Labs C19 and C20 of the Idaho National Laboratory Research Center. The CCL was established under the Next Generation Nuclear Plant Project to support graphite and ceramic composite research and development activities. The research conducted in this laboratory will support the Advanced Graphite Creep experiments - a major series of material irradiation experiments within the Next Generation Nuclear Plant Graphite program.

The CCL is designed to characterize and test low activated irradiated materials such as high purity graphite, carbon-carbon composites, silicon-carbide composite, and ceramic materials. The laboratory is fully capable of characterizing material properties for both irradiated and nonirradiated materials. This report summarizes the major infrastructural modifications undertaken to support this new radiological facility at Idaho National Laboratory.
\end{abstract}




\section{CONTENTS}

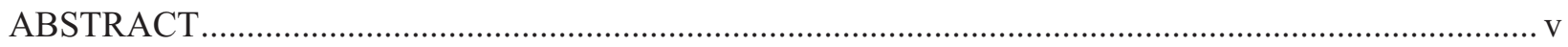

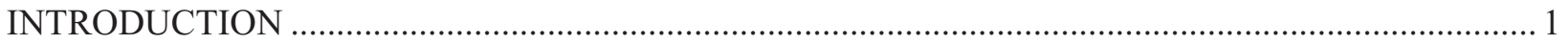

Appendix A-Drawings 601163, 601164 and 764370 Illustrating CCL Irradiated Sample Storage

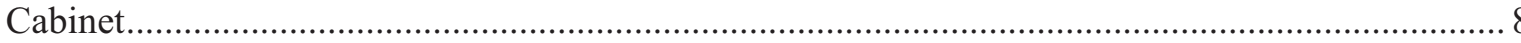

\section{FIGURES}

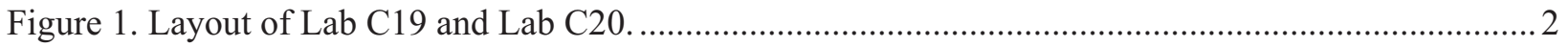

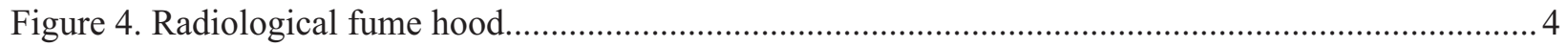

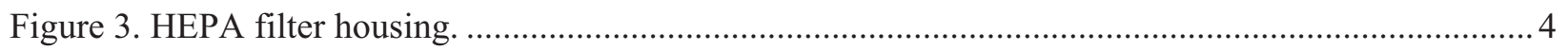

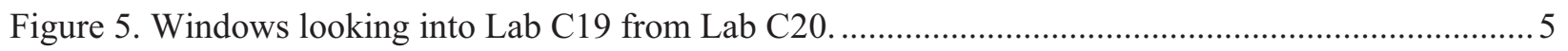

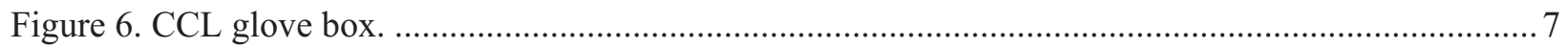

\section{TABLES}

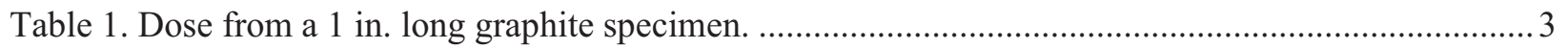

Table 2. Detailed modifications to Lab C19 radiological facility........................................................... 5

Table 3. CCL measurement and test equipment. .................................................................................. 6 


\section{Laboratory for Characterization of Irradiated Graphite}

\section{INTRODUCTION}

The newly completed Carbon Characterization Laboratory (CCL) is located in Labs C19 and C20 of the Idaho National Laboratory (INL) Research Center (IRC). The CCL was established under the Next Generation Nuclear Plant (NGNP) Project to support graphite and ceramic composite research and development activities. The research supports the Advanced Graphite Creep (AGC) experiments - a series of major material irradiation experiments within the NGNP Graphite program.

The CCL is designed to characterize and test low activated irradiated materials such as high purity graphite, carbon-carbon composites, and silicon-carbide composite materials. The laboratory is fully capable of characterizing material properties for both irradiated and nonirradiated materials.

The combined CCL uses Lab C20 as a standard laboratory where testing and characterization of nonirradiated samples are performed. Currently, thermal, physical, and some nondestructive examination techniques are used to characterize the AGC samples before irradiation. Lab C20 also serves as the entrance to Lab C19, which is the radiological laboratory. Lab C19 will have similar characterization capability as Lab C20 but with the added ability for mechanical testing. Figure 1 shows the lab layout. 


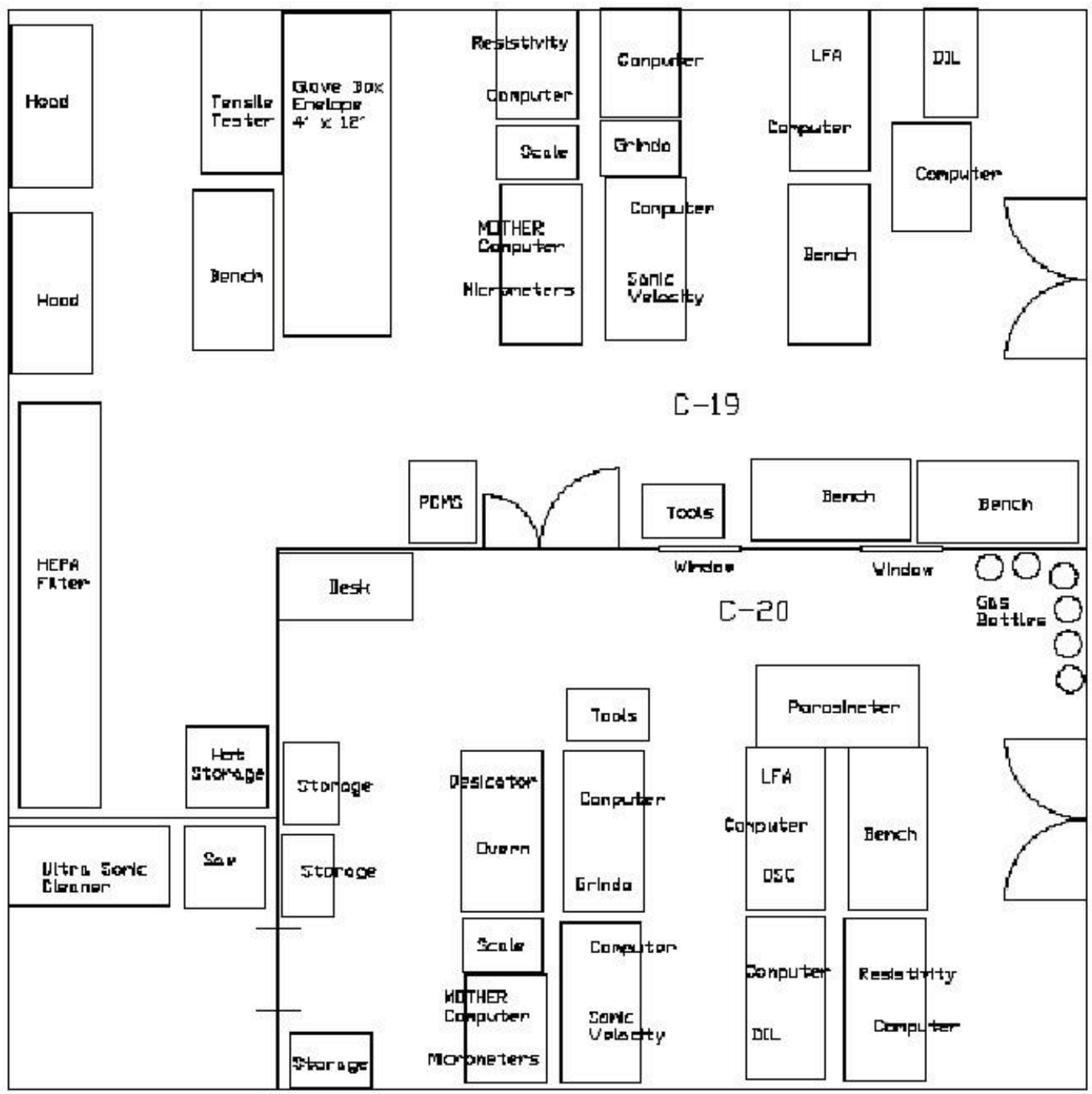

Figure 1. Layout of Lab C19 and Lab C20.

\section{DESCRIPTION}

Lab C19 has been modified to characterize irradiated material specimens. Currently, this facility is being prepared for a large graphite characterization campaign in support of the NGNP Project. Graphite characterization involves the handling of nonsealed irradiated graphite, so the lab was given a Radiological Hazard facility categorization and a National Emission Standards for Hazardous Air Pollutants (NESHAPS) inventory evaluation. It was verified that the total radioactive inventory will remain under the criteria for a less than Hazard Category 3 (non-nuclear) facility and remains below 40 CFR 61, Appendix E values for NESHAPS consideration. The engineering controls for radiological contamination in the workplace environment were evaluated in ECAR-469, "Radiological Control Recommendations for Post Irradiation Examination of Activated Graphite Performed at IRC."

Irradiated materials to be tested and characterized in the CCL are assumed to have low activation levels. To further reduce personnel exposure only a limited number of specimens will be out of controlled, shielded storage at any one time for testing. For the handling of samples from current NGNP activities in the CCL, Table 1 gives the expected radiological dose from a single graphite specimen that is $1.0 \mathrm{in.} \mathrm{long}$ and $0.5 \mathrm{in}$. in diameter. When a sample is not being actively tested, it will be stored in 
shielded storage to reduce personnel exposure. The current shielded storage facility stationed inside Lab C19 is designed to provide shielding for the total number of samples anticipated in an AGC capsule (approximately 500 samples). The anticipated radiation level at the outer surface of a fully loaded storage system is calculated to be $5 \mathrm{mR}$. Appendix A gives details on the AGC sample storage system.

Table 1. Dose from a 1 in. long graphite specimen.

\begin{tabular}{|c|c|}
\hline $\mathbf{m R} / \mathbf{h r}$ & $\begin{array}{c}\text { Distance to specimen } \\
\text { (in.) }\end{array}$ \\
\hline $3.68 \times 103$ & 0.8 \\
\hline 441 & 2.3 \\
\hline 15.5 & 13 \\
\hline 1.44 & 39.6 \\
\hline
\end{tabular}

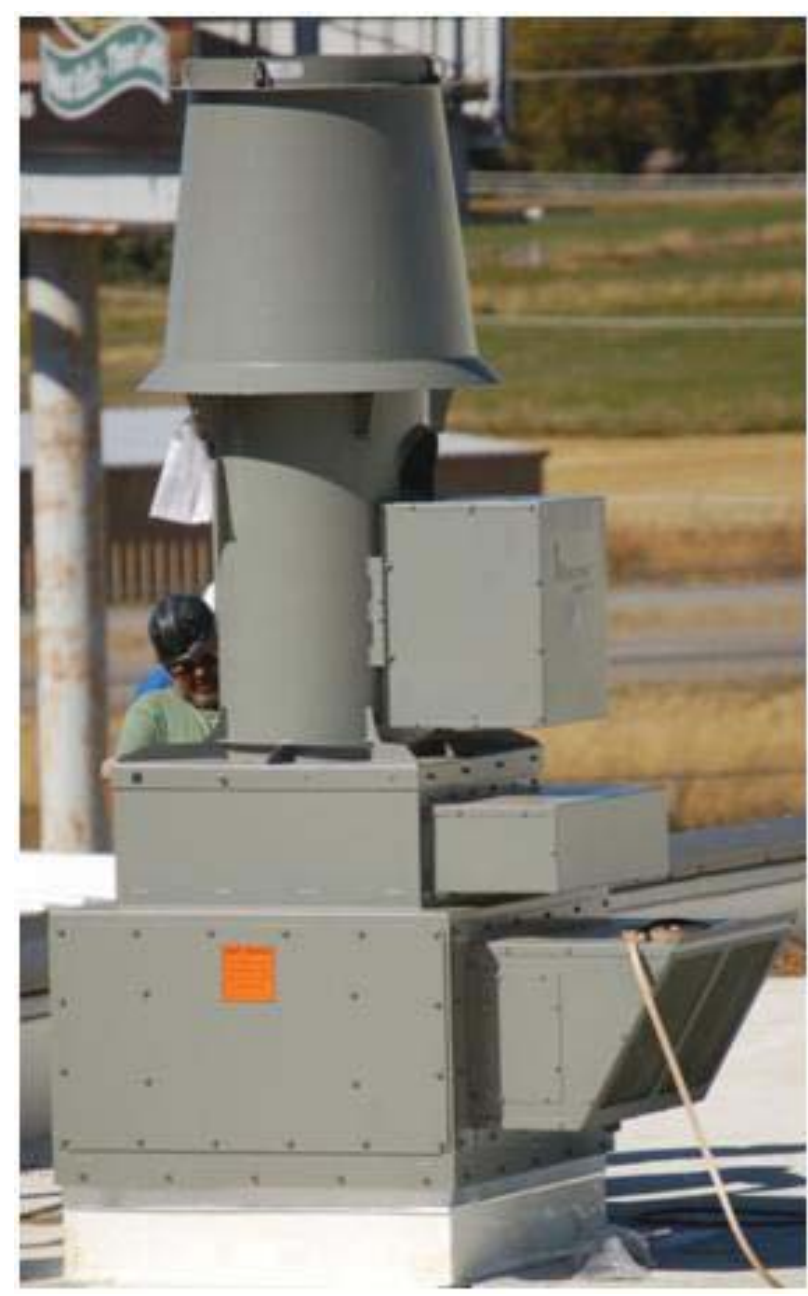

Figure 2. Roof top exhaust blower
The air in Lab C19 will have a negative pressure to contain any contamination that may be released during testing. The additional air flow will be maintained by a make-up air supply from the IRC. A new independent exhaust system was installed in Lab C19 to ensure that all gases and air born particles are exhausted separate from the rest of the IRC building. The new welded stainless steel HEPA filtered ducting system inside Lab C19 directs air flow from the radiological fume hood through HEPA filters to a roof mounted continuously running exhaust fan. This new fan is designed to replace the need for a tall exhaust stack because the high velocity fan adds dilution air then pushes the exhaust many feet straight up before it dissipates. Figure 2 is a photograph of the exhaust blower.

The new HEPA filter housing is a $2 \times 1$ bagin/bag-out, side access design as shown in Figure 3. Phoenix ${ }^{\mathrm{TM}}$ variable air volume valves and balancing dampers were installed for the air distribution system. Ducts and diffusers were removed from the ceiling to cap off the existing HVAC system and replaced with new ductwork to connect to the independent exhaust system. The new exhaust control system is integrated with the existing IRC Carrier Control System to assist with the additional air flow required for the make-up air. 


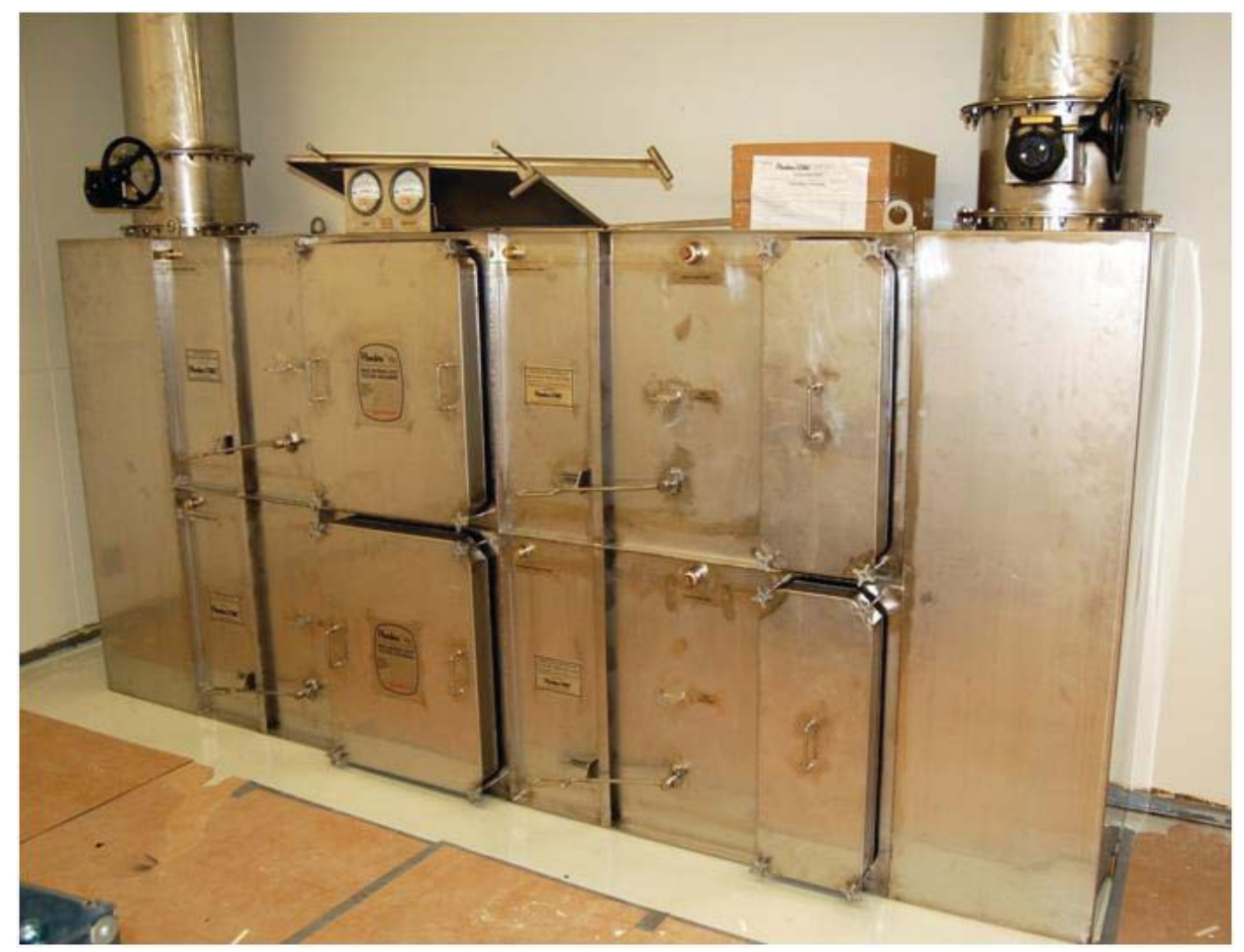

Figure 3. HEPA filter housing.

An exhaust fume hood (Figure 4) has been installed for tasks that may generate contamination, such as cutting and mechanical testing. Two large windows were installed in the wall separating Lab C19 and C20 to allow personnel to view work being performed in Lab C19, as shown in Figure 5. A portal monitor used to detect contamination on personnel will control egress from the radiological facility. The arrangement of work tables, equipment, storage cabinets and desks within the radiological facility was devised to ensure the maximum contamination control for the facility and personnel protection. Table 2 lists the specific modifications that occurred in Lab C19.

Similar material property tests will be performed in both labs for the current graphite characterization campaign in support of the AGC program. The thermal and physical properties of the nonirradiated graphite samples will be characterized in Lab C20 before the samples are irradiated in the reactor. After irradiation, the same samples will be recharacterized in Lab C19 using identical material property testing procedures. Testing details are described in INL/EXT-09-15515 "Carbon Characterization Laboratory Report."

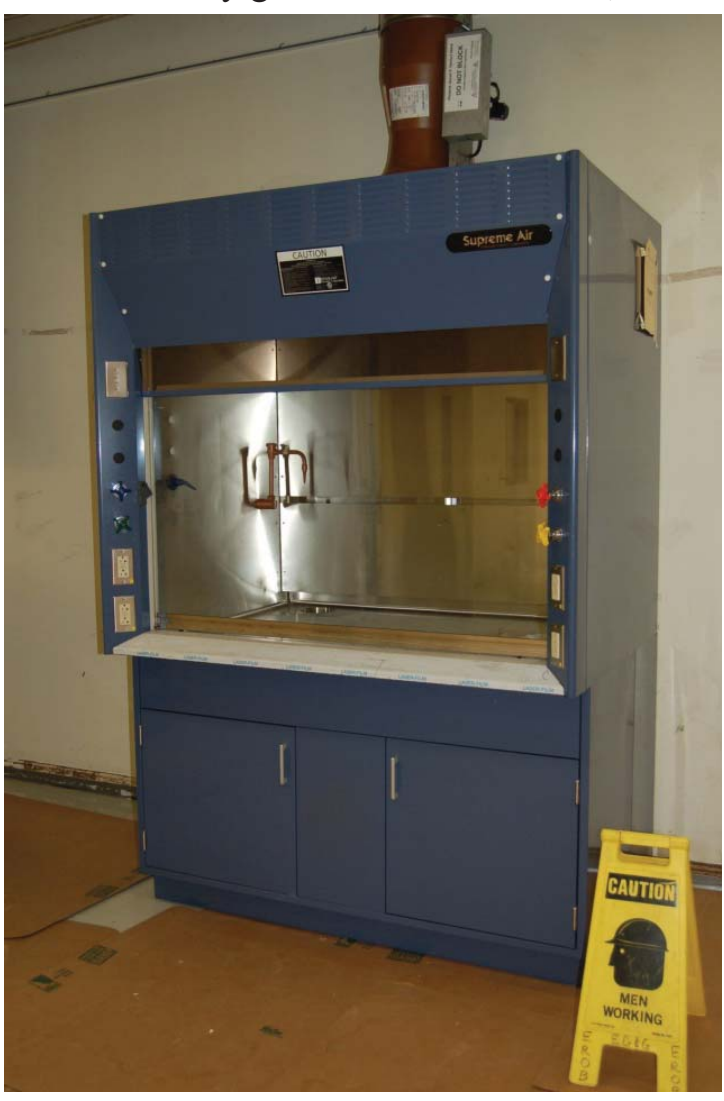

Figure 4. Radiological fume hood. 


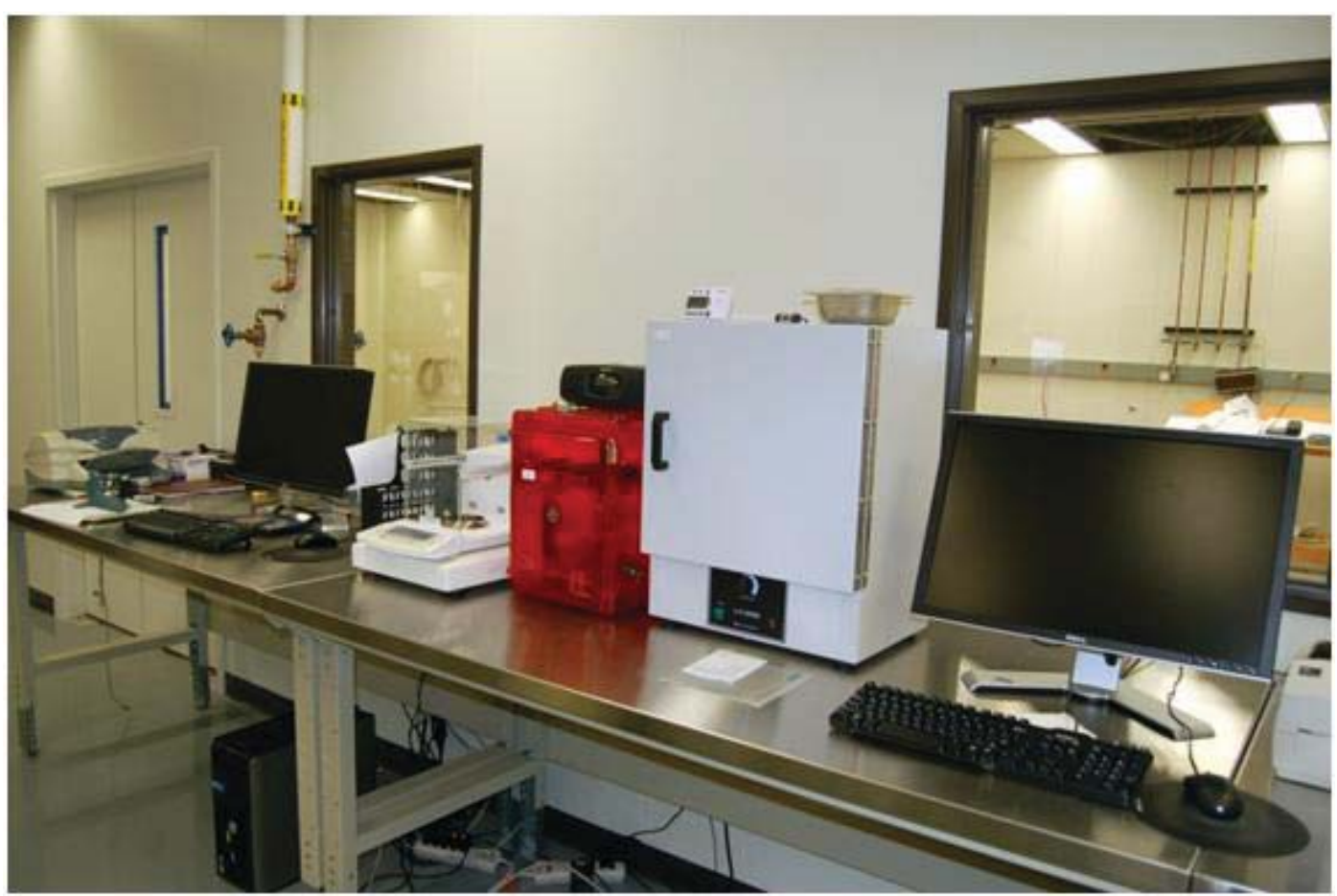

Figure 5. Windows looking into Lab C19 from Lab C20.

Table 2. Detailed modifications to Lab C19 radiological facility.

\begin{tabular}{|l|l|}
\hline \multicolumn{1}{|c|}{ Demolition } & \multicolumn{1}{c|}{ Installation } \\
\hline Removal of existing walls & New walls between Labs C19 and C20 \\
Removal of electrical power conduits, receptacles & A door between Labs C19 and C20, 5 ft wide \\
and switches from the walls & Two windows in wall between Labs C19 and C20 \\
Removal of gas lines and utilities from the walls & New electrical panels, power conduit poles and \\
Ducts and diffusers were removed from the ceiling & internet cabling \\
to cap off the existing HVAC system & New epoxy floor surface \\
Original flooring was removed & Independent exhaust system, HEPA filtered with \\
& new ductwork \\
& New radiological fume hood \\
& New portal monitor to control egress \\
& New tables and characterization equipment \\
& New radiological glove box \\
\hline
\end{tabular}

Similar to how work is performed in Lab C20, separate stations are set up within the radiological facility. Lab C19 will allow full thermal, physical, and mechanical testing capability for low activated irradiated material specimens. Following the facility modifications described, the radiological laboratory will be outfitted with the necessary characterization equipment, recorded in Table 3. 
Table 3. CCL measurement and test equipment.

\begin{tabular}{|c|c|c|c|c|}
\hline Measurement & Standard & Instrumentation & Calibration & Result \\
\hline $\begin{array}{l}\text { Physical } \\
\text { dimensions }\end{array}$ & ASTM C559 & $\begin{array}{l}\text { Mitutoyo Micrometer 121-155 } \\
\text { Mitutoyo Caliper CD-6" CSX }\end{array}$ & INL & Bulk Density \\
\hline Mass & ASTM C559 & Sartorius Scale ME235P & INL & Bulk Density \\
\hline Sonic Resonance & ASTM C747 & J. W. Lemmens Grindosonic & $\begin{array}{l}\text { None } \\
\text { required }\end{array}$ & Elastic Modulus \\
\hline Sonic Velocity & ASTM C769 & $\begin{array}{l}\text { Olympus NDT Square Wave } \\
\text { Pulser/Receiver 5077PR } \\
\text { National Instruments Digitizer } \\
\text { USB } 5133\end{array}$ & INL & $\begin{array}{l}\text { Young's modulus, } \\
\text { Shear modulus, } \\
\text { Poisson ratio }\end{array}$ \\
\hline 4-point resistivity & ASTM C611 & $\begin{array}{l}\text { Kiethly } 6220 \text { Precision Current } \\
\text { Source }\end{array}$ & INL & Electrical resistivity \\
\hline $\begin{array}{l}\text { Laser flash } \\
\text { diffusivity }\end{array}$ & ASTM E1461 & Netzsch LFA 457 & $\begin{array}{l}\text { Calibration } \\
\text { by user }\end{array}$ & Thermal diffusivity \\
\hline $\begin{array}{l}\text { Push rod } \\
\text { dilatometry }\end{array}$ & ASTM E228 & Netzsch DIL 402C & $\begin{array}{l}\text { Calibration } \\
\text { by user }\end{array}$ & $\begin{array}{l}\text { Coefficient of } \\
\text { Thermal Expansion }\end{array}$ \\
\hline Tensile testing & $\begin{array}{l}\text { ASTM C749 } \\
\text { ASTM C781 }\end{array}$ & $\begin{array}{l}\text { Instron } 5582 \\
\text { Epsilon } 3560 \text { Extensometer }\end{array}$ & $\begin{array}{l}\text { INL } \\
\text { Calibration } \\
\text { by user } \\
\end{array}$ & $\begin{array}{l}\text { Tensile strength, } \\
\text { elongation to failure, } \\
\text { elastic modulus }\end{array}$ \\
\hline Flexural testing & ASTM C651 & $\begin{array}{l}\text { Instron } 5582 \\
\text { Epsilon } 3540 \text { Deflectometer }\end{array}$ & $\begin{array}{l}\text { INL } \\
\text { Calibration } \\
\text { by user }\end{array}$ & Flexural strength \\
\hline $\begin{array}{l}\text { Compressive } \\
\text { testing }\end{array}$ & ASTM C695 & $\begin{array}{l}\text { Instron } 5582 \\
\text { Epsilon } 3540 \text { Deflectometer }\end{array}$ & $\begin{array}{l}\text { INL } \\
\text { Calibration } \\
\text { by user }\end{array}$ & $\begin{array}{l}\text { Compressive strength, } \\
\text { compressive modulus }\end{array}$ \\
\hline
\end{tabular}

Since mechanical testing is destructive and will likely produce some level of contamination during failure, all mechanical testing specimens will be attached to the testing fixtures in the fume hood and placed in a transfer bag. The transfer bag will be placed inside an enclosure on the testing machine and attached to the appropriate test fixtures.

As the specimen is broken, fracture remnants will be captured in the transfer bag. Any particulate outside of the transfer bag will be exhausted from the enclosure to the exhaust system.

Finally, while not part of the actual facility modification activities, a glove box is being procured and installed for those occasional samples that have higher than anticipated radiation levels. This glove box will be vented to the exhaust system servicing the radiological facility. The glove box will be used for all activities where measured levels of contamination or activity exceed the normal range (i.e., sample repackaging, sample cutting, general handling of high activity samples, etc.). It will be designed to accommodate most of the characterization equipment so that testing can be conducted on higher radiation level samples if needed (see Figure 6 for a drawing of glove box). 


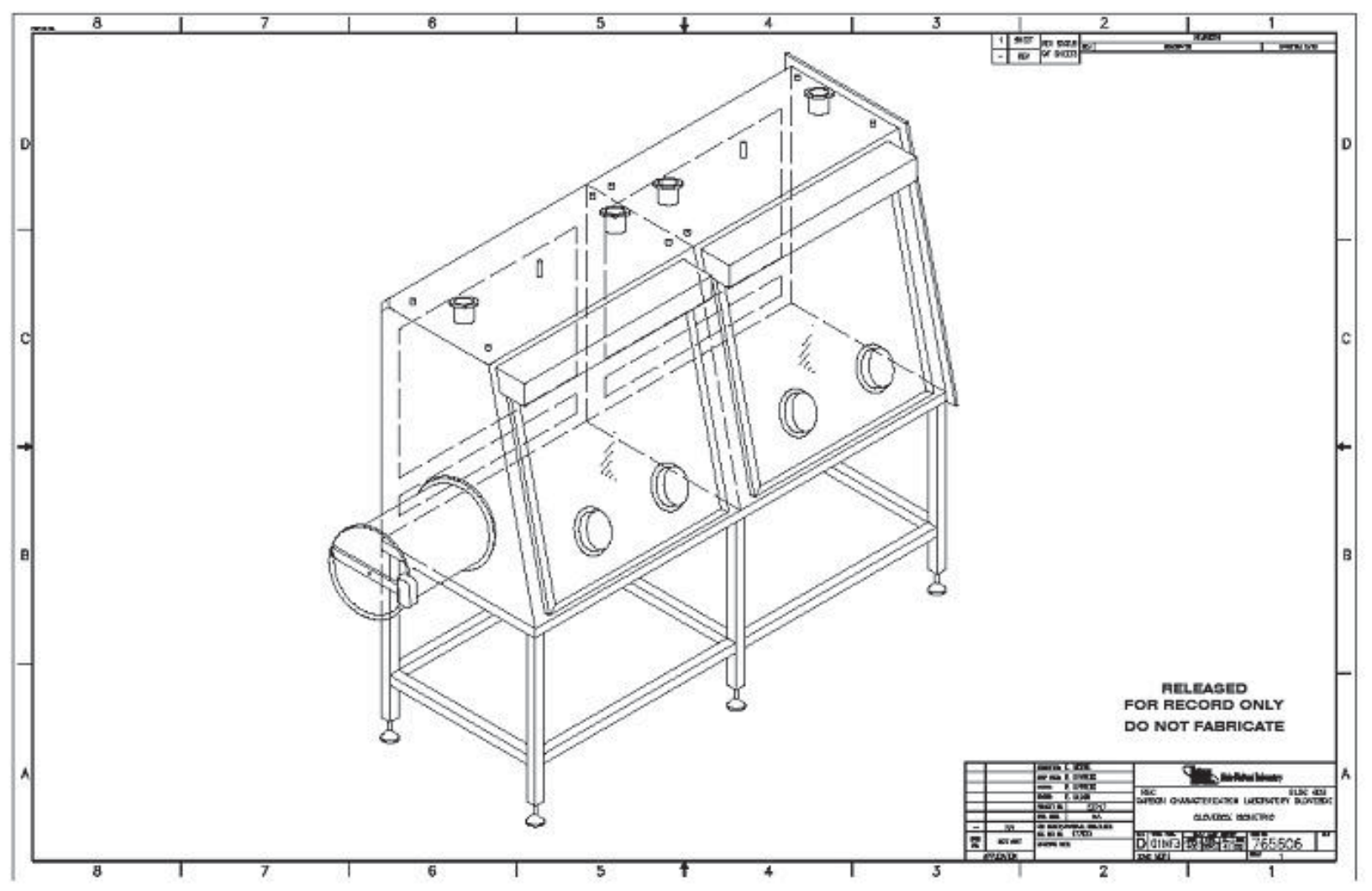

Figure 6. CCL glove box.

The characterization equipment (including the glovebox discussed previously) will be installed in Lab C19 over the next 6 to 12 months. A Radiological Work Permit will be created and a dry run performed to ensure that all training and monitoring systems are in place. Work in Lab C19 will require RadWorker II certification and work in the CCL glove box will require glove box training as stated in Lab Instructions LI-1577-09-IRC. 


\section{Appendix A}

\section{Drawings 601163, 601164 and 764370 Illustrating CCL Irradiated Sample Storage Cabinet}




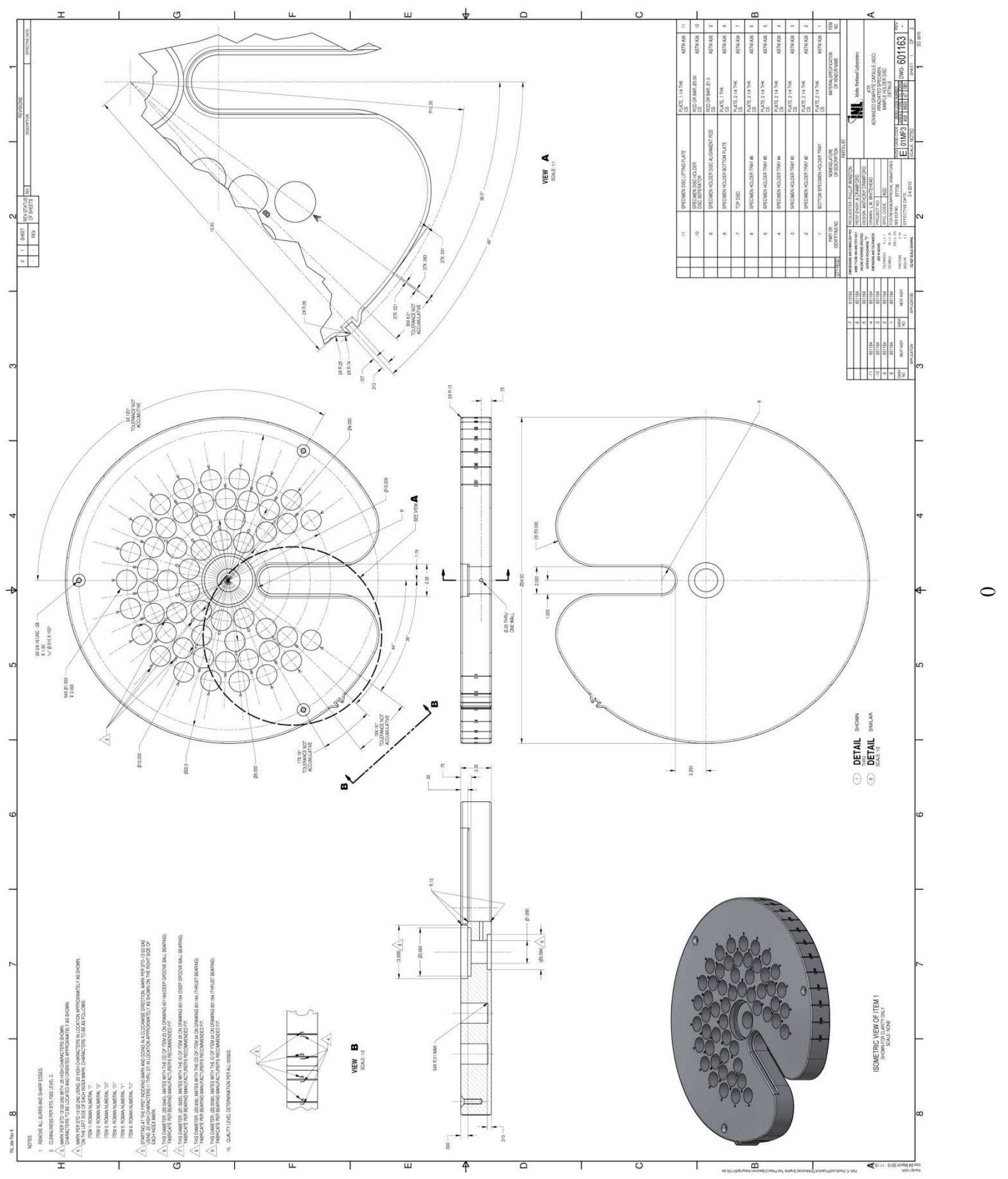




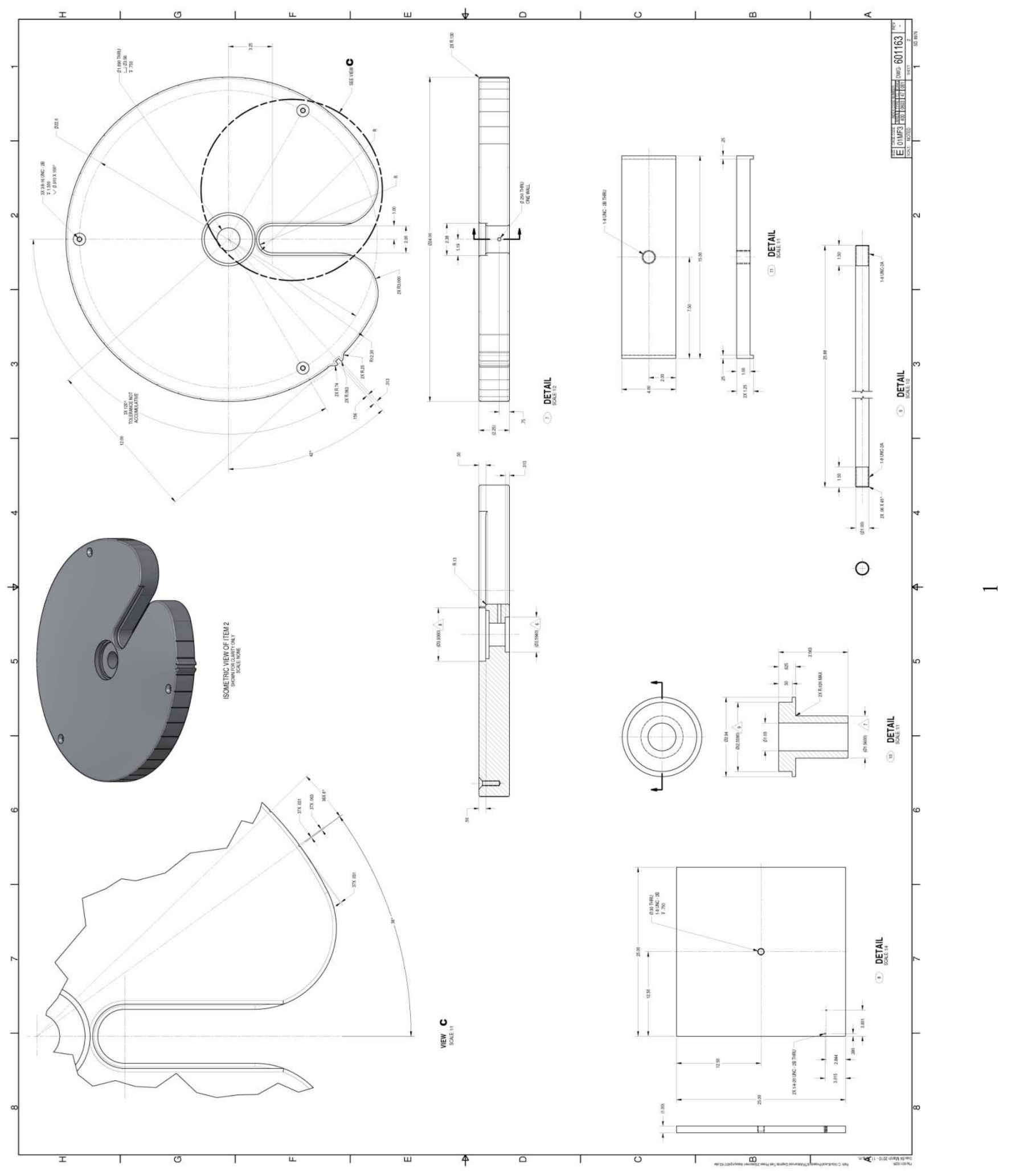




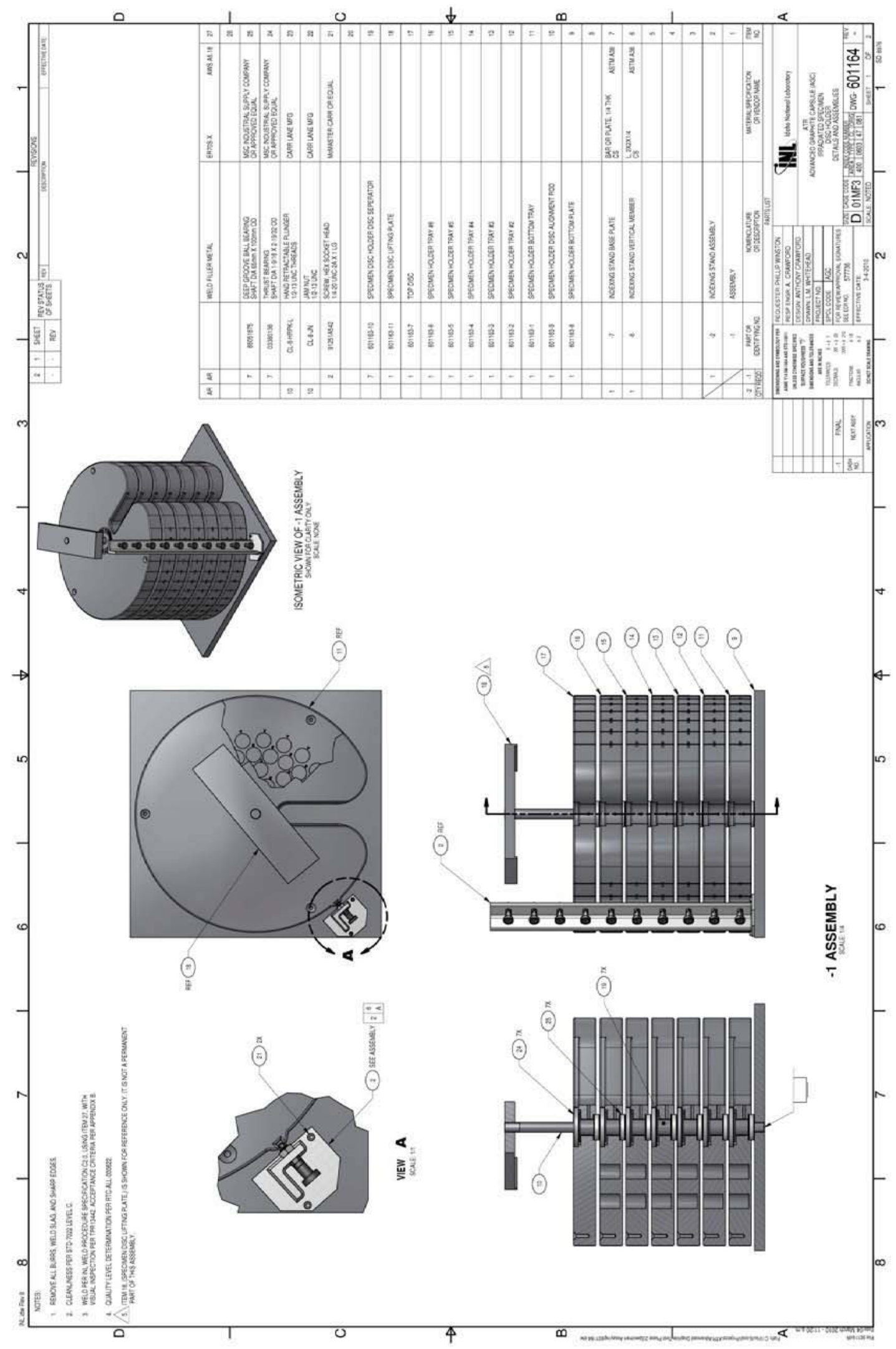




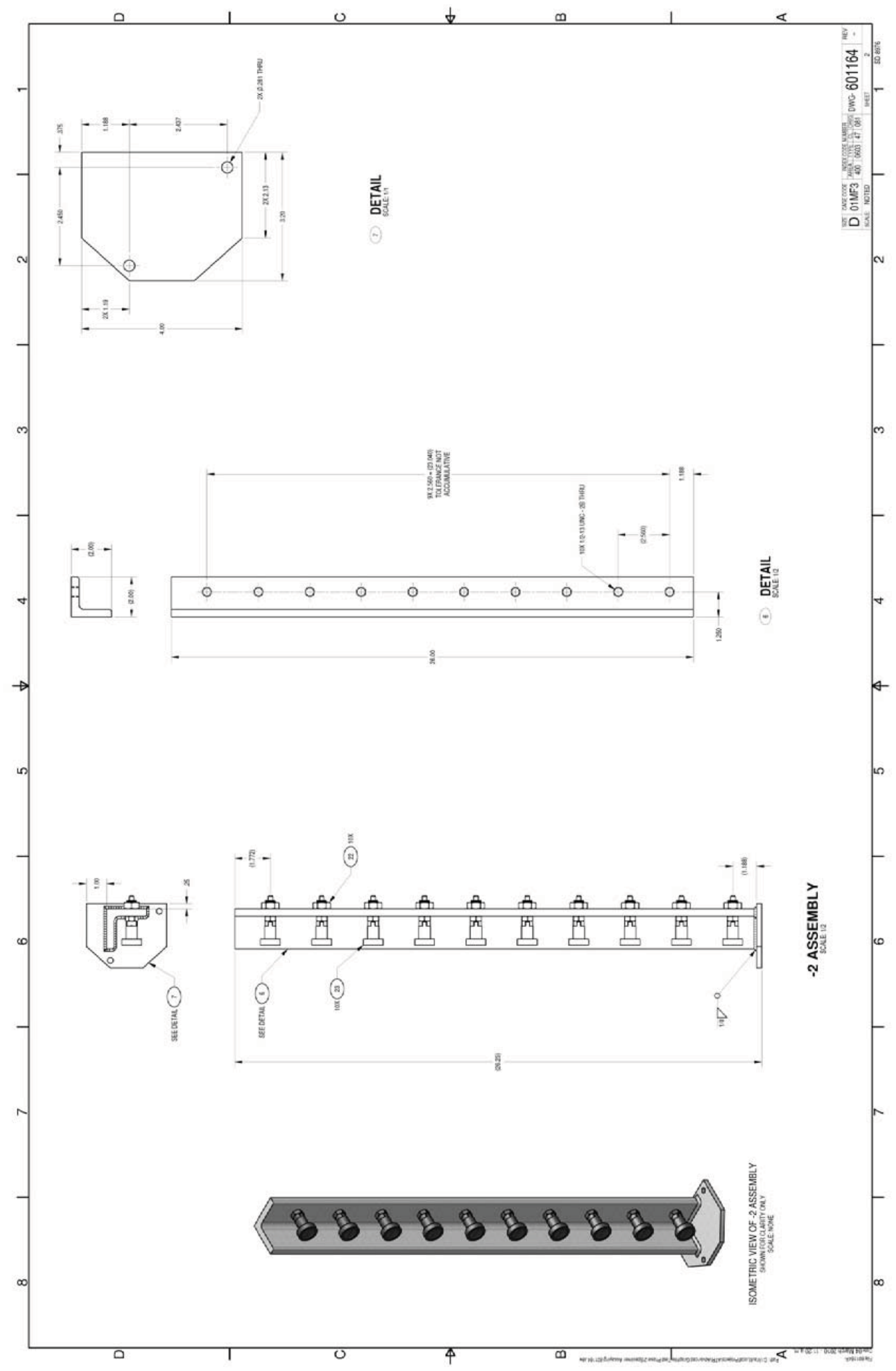




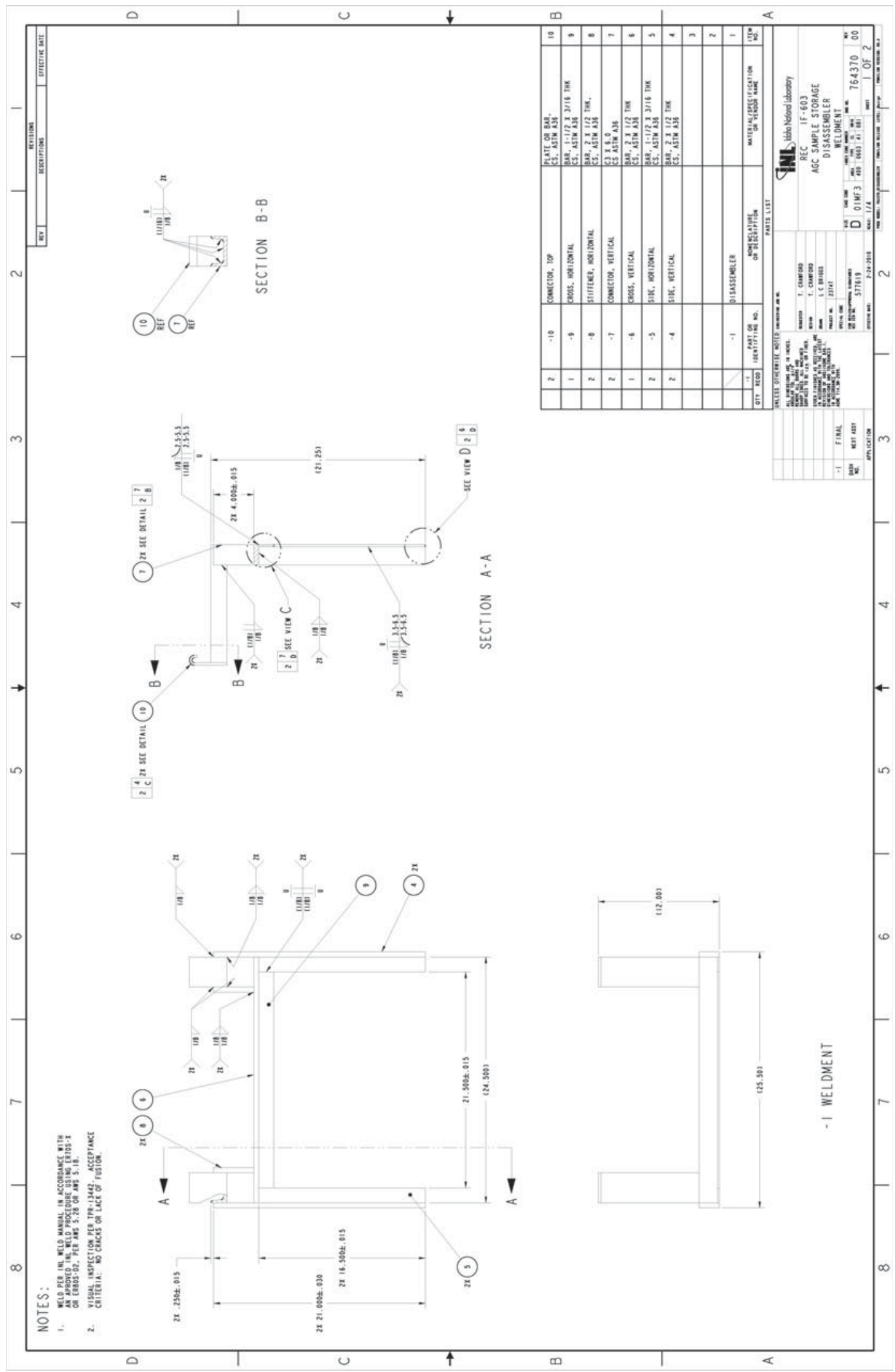




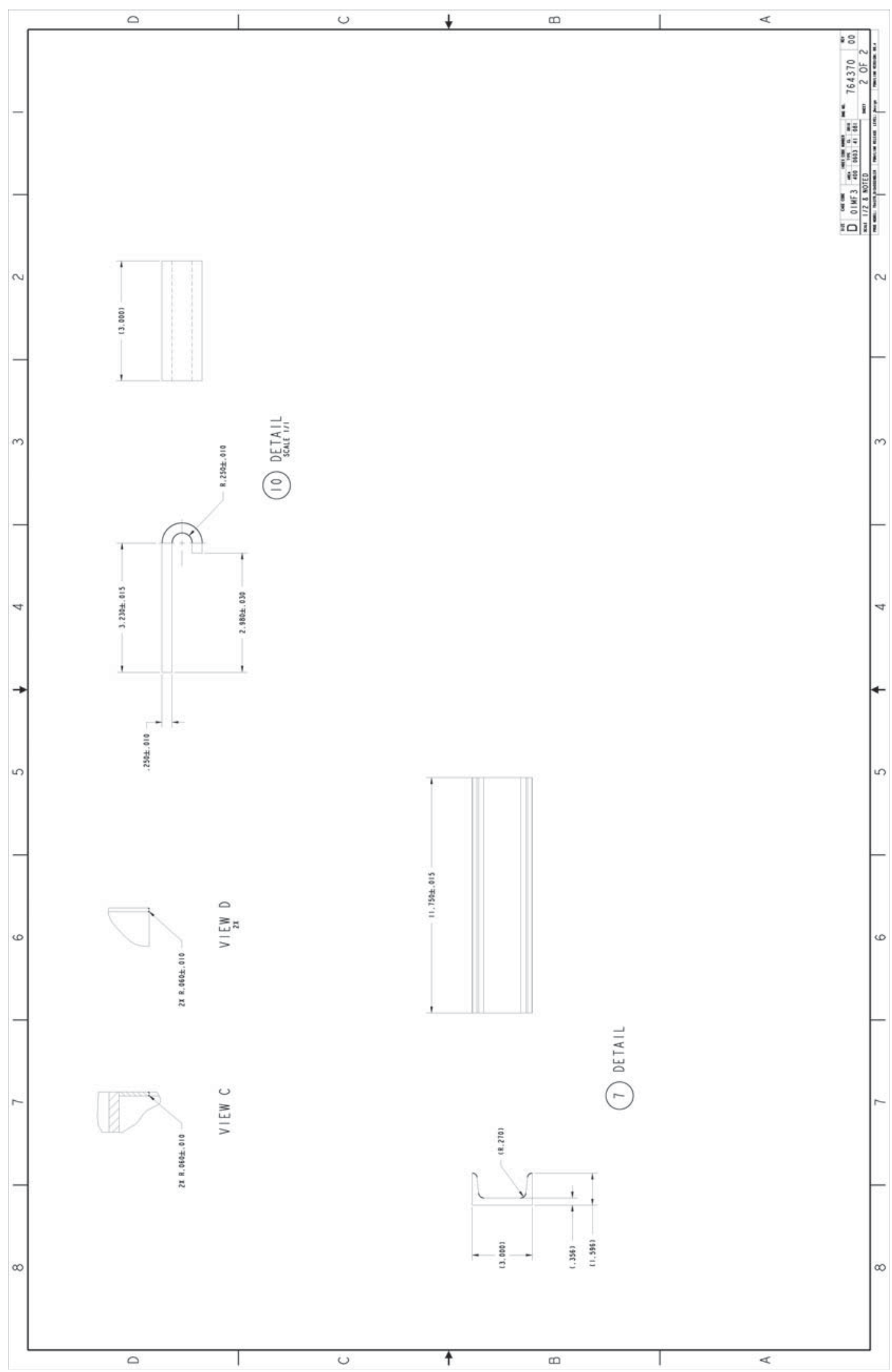

